\title{
ANALISIS KEPUASAN WISATAWAN \\ TERHADAP DAYA TARIK WISATA MALIOBORO KOTA YOGYAKARTA
}

\author{
Aris Baharuddin', Maya Kasmita ${ }^{2}$, Rudi Salam ${ }^{3}$ \\ ${ }^{1}$ Politeknik Informatika Nasional Makassar \\ ${ }^{2,3}$ Universitas Negeri Makassar \\ Email : aris.baharuddin@yahoo.com
}

\begin{abstract}
ABSTRAK
Penelitian ini bertujuan untuk mengetahui kepuasan wisatawan terhadap daya tarik wisata dengan pendekatan deksriptif kuantitatif. Penelitian ini dilakukan di Jalan Malioboro, Yogyakarta, Provinsi Daerah istimewa Yogyakarta. Waktu penelitiannya dilaksanakan pada bulan april 2015. Adapun sumber data dalam penelitian ini adalah data primer dan sekunder. Dalam penelitian ini data diperoleh dari wawancara langsung dan pengisian kuisioner yang ada di obyek wisata Malioboro, Yogyakarta. Metode pengumpulan data pada prinsipnya berfungsi untuk mengungkapkan variabel yang akan diteliti. Dalam penelitian ini metode pengumpulan data yang digunakan adalah: 1) Observasi, 2) Dokumentasi, 3) Wawancara, 4) Kuisoner. Adapun analisis data yang dilakukan adalah 1) analisis karakteristik responden, 2) analisis motivasi pengunjung, 3) Analisis Biaya Perjalanan. Hasil penelitian menunjukkan puas terhadap daya tarik wisata Malioboro hal tersebut, dapat dilihat dari 1) pemandangan, 2) Akses/keterjangkauan, 3) keamanan dan kenyamanan, 4) fasilitas yang tersedia, 5) infrastruktur jalan, 6) pelayanan, penerangan dan informasi. Dari keenam indikator tersebut, menunjukkan dalam kategori baik.
\end{abstract}

Kata Kunci: Motivasi Kerja, Pelayanan Publik

\section{PENDAHULUAN}

Objek wisata yang ada di Indonesia merupakan salah satu kekayaan alam yang patut dibanggakan dan setiap daerah mempunyai ciri khas yang menarik wisatawan untuk mengungjungi tempat tersebut. Pariwisata merupakan sektor yang potensial untuk dikembangkan sebagai salah satu sumber pendapatan daerah. Usaha memperbesar pendapatan asli daerah, maka program pengembangan dan pendayagunaan sumber daya dan potensi pariwisata daerah diharapkan dapat memberikan sumbangan bagi pembangunan ekonomi.

Pariwisata merupakan suatu perjalanan yang dilakukan seseorang untuk sementara waktu yang diselenggarakan dari suatu tempat ketempat lain dengan meninggalkan tempat semula dan dengan suatu perencanaan atau bukan maksud mencari nafkah di tempat yang dikunjunginya, tetapi semata mata untuk menikmati kegiataan pertamasyaan atau reakreasi untuk memenuhi keinginan yang beraneka ragam.

Secara luas pariwisata dipandang sebagai kegiatan yang mempunyai multidimensi dari rangkaian suatu proses pembangunan. Pembangunan sektor pariwisata menyangkut aspek sosial budaya, ekonomi dan politik (Spillane, 2004:14). Hal tersebut sejalan dengan yang tercantum 
108|Ad'ministrare, Vol. 3 No. 2, 2016

dalam Undang-Undang Nomor 10 tahun 2009 Tentang Kepariwisataan yang menyatakan bahwa Penyelenggaraan Kepariwisataan ditujukan untuk meningkatkan pendapatan nasional dalam rangka meningkatkan kesejahteraan dan kemakmuran rakyat, memperluas dan memeratakan kesempatan berusaha dan lapangan kerja, mendorong pembangunan daerah, memperkenalkan dan mendayagunakan obyek dan daya tarik wisata di Indonesia serta memupuk rasa cinta tanah air dan mempererat persahabatan antar bangsa.

Majunya industri pariwisata suatu daerah sangat bergantung kepada jumlah wisatawan yang datang, karena itu harus ditunjang dengan peningkatan pemanfaatan daerah tujuan wisata (DTW) sehingga industri pariwisata akan berkembang dengan baik.

Yogyakarta merupakan salah satu tempat wisata yang dapat dijadikan tujuan saat liburan. Mulai dari wisata alam, wisata sejarah, wisata budaya, dan wisata kuliner. Yogyakarta memiliki banyak tempat wisata diantaranya, malioboro, candi Borobudur. Salah satu objek wisata di Yogyakarta yang menjadi tujuan para wisatawan yaitu Malioboro. Malioboro merupakan salah satu tempat wisata belanja yang terkenal di Yogyakarta. Tempat ini dikenal dengan pedagang kaki lima yang menjual berbagai macam cinderamata yang berjejeran di sepanjang jalan malioboro.

\section{KAJIAN TEORI}

Menurut etimologi kata "pariwisata" identik dengan kata "travel" dalam bahasa inggris yang diartikan sebagai perjalanan yang dilakukan berkali-kali dari satu tempat ke tempat lain. Menurut definisi yang luas, pariwisata adalah perjalanan dari suatu tempat ke tempat lain, yang bersifat sementara dan dilakukan perorangan atau kelompok sebagai usaha mencari keseimbangan atau keserasian dan kebahagiaan denganlingkungan hidup dalam dimensi sosial, budaya, alam dan ilmu (Spillane, 1987 : 21). Menurut UU RI No. 9 tahun 1990 pasal 7 tentang kepariwisataan "Pariwisata adalah segala sesuatu yang berhubungan dengan wisata termasuk pengusaha obyek dan daya tarik wisata, usaha sarana pariwisata, dan usaha lain dibidang tersebut".

Dalam kegiatan kepariwisataan ada yang disebut subyek wisata yaitu orang-orang yang melakukan perjalanan wisata dan objek wisata yang merupakan tujuan wisatawan. Bermacammacam pendapat para ahli mengenai definisi pariwisata, seperti yang diungkapkan oleh Spilande (1985), Pendit (1994), Yoeti (1996) yang mengungkapkan suatu perjalanan yang dilakukan oleh seseorang atau kelompok dalam menemukan kebahagiaan baik dalam dimensi sosial, budaya, alam, dan ilmu.

Upaya meningkatkan kunjungan pariwisata tentunya harus didukung oleh daya tarik wisata yang memadai. Secara garis besar daya tarik wisata dapat diklasifikasikan ke dalam tiga kategori, yakni, daya tarik alam, daya tarik budaya dan daya tarik buatan manusia (Marpaung, 2000: 76). Sedangkan dalam Undang-Undang Nomor 10 Tahun 2009 tentang Kepariwisataan, dikemukakan pengertian daya tarik wisata bahwa segala sesuatu yang memiliki keunikan, keindahan, dan nilai yang berupa keanekaragaman kekayaan alam, budaya dan hasil buatan manusia yang menjadi sasaran atau tujuan 
kunjungan wisatawan. Selanjutnya, dengan memberikan daya tarik wisata tentunya para wisatawan akan tertarik untuk berkunjung di wilayah tersebut. Adapun Adapun faktor yang mempengaruhi kunjungan wisatawan, yaitu: 1) harga, 2) pendapatan, 3) sosial budaya, 4) intensitas keluarga. Kunjungan wisatawan tentunya mempengaruhi faktor tersebut, karena dari keempat faktor tersebut memiliki keterkaitan satu sama lain.

\section{METODE PENELITIAN}

Penelitian ini dilakukan di Jalan Malioboro, Yogyakarta, Provinsi Daerah istimewa Yogyakarta. Waktu penelitiannya dilaksanakan pada bulan april 2015. Data yang digunakan dalam penelitian ini yaitu, data primer. Dalam penelitian ini data diperoleh dari wawancara langsung dan pengisian kuisioner yang ada di obyek wisata Malioboro, Yogyakarta. Metode pengumpulan data pada prinsipnya berfungsi untuk mengungkapkan variabel yang akan diteliti. Dalam penelitian ini metode pengumpulan data yang digunakan adalah: 1) Observasi, 2) Dokumentasi, 3) Wawancara, 4) Kuisoner. Adapun analisis data yang dilakukan adalah 1) analisis karakteristik responden, 2) analisis motivasi pengunjung, 3) Analisis Biaya Perjalanan.

\section{HASIL DAN PEMBAHASAN}

Upaya dalam menarik wisatawan untuk berkunjung suatu daerah tentunya harus memberikan ciri khas tersendiri yang mampu memberikan kesenangan kepada para wisatawan untuk senantiasa menikmati daya tarik wisata. Dalam penelitian ini, untuk mengetahui kepuasan wisatawan di daya tarik wisata Malioboro di Kota Yogyakarta, maka ada 6 indikator yaitu, 1) pemandangan, 2) Akses/keterjangkauan, 3) keamanan dan kenyamanan, 4) fasilitas yang tersedia, 5) infrastruktur jalan, 6) pelayanan, dan informasi. Sebelum membahas dari keenam indikator penelitian, maka terlebih dahulu akan disajikan pada tabel 1 tentang tingkat kepuasan wisatawan yang berkunjung.

Tabel 1 Kepuasan Wisatawan yang berkunjung

\begin{tabular}{|l|l|r|r|r|r|}
\hline \multirow{2}{*}{ No. } & \multicolumn{4}{|c|}{ Frekuensi (\%) } \\
\cline { 3 - 6 } & & \multicolumn{1}{|c|}{ SB } & B & CB & \multicolumn{1}{c|}{ KB } \\
\hline \hline 1 & Pemandangan & 11,67 & 61,67 & 15,00 & 11,67 \\
\hline 2 & Akses/keterjangkauan & 6,67 & 46,67 & 45,00 & 8,33 \\
\hline 3 & Keamanan dan kenyamanan & 18,33 & 51,67 & 26,67 & 3,33 \\
\hline 4 & Fasilitas yang tersedia & 11,67 & 55,00 & 30,00 & 3,33 \\
\hline 5 & Infrastruktur jalan & 10,00 & 48,33 & 31,67 & 10,00 \\
\hline 6 & Pelayanan, dan Informasi & 13,33 & 58,33 & 25,00 & 3,33 \\
\hline
\end{tabular}

Keterangan

SB : Sangat Puas

B : Puas

CB : Cukup Puas 
110 |Ad'ministrare, Vol. 3 No. 2, 2016

KB : Kurang Puas

\section{Pemandangan}

Wisata Malioboro merupakan daya tarik wisata di Kota Yogyakarta yang memiliki Pemandangan yang tidak kalah dengan pemandangan di nusantara. Hal ini disebabkan karena daya tarik wisata tersebut, menyediakan berbagai keindahan yang tidak memiliki batas waktu untuk berkunjung selama 24 jam. Berdasarkan informasi tersebut, sesuai dengan penilaian wisatawan yang berkunjung yang memberikan informasi bahwa pemandangan menarik atau puas yang menunjukkan persentase 61,67 persen. Wisata tersebut, merupakan daya tersendiri bagi wisatawan karena merupakan pusat kota Yogyakarta yang menyediakan berbagai macam keindahan seperti: menampilkan berbagai macam ritual, menyediakan berbagai macam kerajinan batik, souvenir, angkringan, bakul bakso, lesehan, tukang becak, tukang andong. Selain itu, wisata Malioboro dijadikan sebagai tempat para seniman mengekspresikan kreatifitasnya, sehingga para wisatawan bisa melihat dan belajar tentang kerajinan yang dimiliki.

\section{Akses/keterjangkuan}

Salah satu daya tarik bagi wisata yang berkunjung terhadap wisata di yogyakarta adalah lokasi yang strategis. Wisata Malioboro merupakan daerah berada di pusat kota Yogyakarta. Selain itu, dikenal sebagai sebagai kawasan Titik Nol Kilometer Kota Yogyakarta. Hal tersebut, sesuai dengan informasi yang disampaikan oleh wistawan yang berkunjung menyatakan bahwa daya tarik wisata Malioboro selain mudah untuk di kunjungi akses jalan tidak terlalu jauh dan mudah diakses baik menggunakan alat transportasi seperti kendaraan roda dua, mobil, dan kendaraan lainnya, baik angkutan pribadi dan angkutan umum.

\section{Keamanan dan kenyamanan}

Selain akses dan pemandangan yang memukau, wisata Malioboro pun menjamin keamanan dan kenyamanan bagi wisatawan yang berkunjung. Berdasarkan hasil angket wisatawan yang berkunjung terlah memeroleh keamanan dan keyamanan yang baik dalam. Hal ini disebabkan karena pihak pemerintahan dalam rangka menjamin keamanan dan kenyamanan wisatawan telah mengeluarkan Peraturan Daerah Provinsi Daerah Istimewa Yogyakarta Nomor 6 Tahun 2008 tentang Organisasi dan Tatakerja Dinas Daerah Provinsi DIY dan Peraturan Gubernur Daerah Istimewa Yogyakarta Nomor 45 Tahun 2008 tentang Rincian dan Tugas Dinas Pariwisata Provinsi DIY. Salah satu dinas yang ditugasi untuk melaksankaan peraturan tersebut, adalah Dinas Pariwisata selain menangani Promosi 
dan Pengembangan Pariwisata DIY diharapkan mampu menciptakan rasa aman dan nyaman para pengunjung serta dibantu oleh instansi yang terkait.

\section{Fasilitas yang tersedia}

Upaya dalam mendukung dan meningkatkan pelayanan yang terbaik bagi wisatawan tentunya harus didukung oleh fasilitas yang memadai. Berdasarkan hasil penelitian terhadap wisatawan yang berkunjung menunjukkan 55 persen yang menyatakan berkategori puas terhadap fasilitas yang disediakan. Hal ini didukung seperti: kendaraan umum yang mudah untuk diperoleh seperti: becak, taksi, sepeda dan alat transportasi lainnya dengan harga yang terjangkau. Selain itu, didukung fasilitas hotel yang memadai serta penyediaan fasilitas umum berupa tempat parkir. Dalam mendukung tempat parkir sejumlah stakeholder telah melakukan kerjasama. Salah satu pihak yang termasuk adalah PT Kereta Api Indonesia juga telah menyiapkan rencana pengembangan Stasiun Tugu untuk mendukung penataan kawasan Malioboro.

\section{Pelayanan, dan informasi.}

Kota Yogyakarta selain terkenal sebagai kota yang indah, juga terkenal sebagai wilayah yang ramah terhadap pengunjung. Berdasarkan informasi tersebut, yang menjadi faktor pendukung Yogyakarta menjadi kota wisata yang ramah. Oleh karena itu, wisatawan yang ini berkunjung tentunya memudahkan untuk memeroleh informasi yang diinginkan. Hal tersebut, sesuai dengan hasil penelitian yang menunjukkan bahwa terdapat 55,33 persen orang yang berada di daya tarik wisata Malioboro bersikap ramah dan mudah untuk memberikan informasi kepada pengunjung akibatnya pengunjung tertarik untuk datang.

\section{SIMPULAN}

Berdasarkan hasil penelitian menunjukkan bahwa daya tarik wisata Malioboro telah memberikan kepuasan tersendiri bagi wisatawan yang berkunjung. Hal tersebut, dilihat dari 6 indikator seperti: 1) pemandangan, 2) Akses/keterjangkauan, 3) keamanan dan kenyamanan, 4) fasilitas yang tersedia, 5) infrastruktur jalan, 6) pelayanan, penerangan dan informasi. Dari keenam indikator tersebut, menunjukkan dalam kategori baik.

\section{DAFTAR PUSTAKA}

A, Yoeti, Oka. Edisi Revisi 1996, Pengantar Ilmu Pariwisata, Penerbit Angkasa, Bandung.

Pendit, I Nyoman, S. 1994. Ilmu Pariwisata Sebuah Pengantar Perdana. Jakarta: Pradnya Paramita. 
112 |Ad'ministrare, Vol. 3 No. 2, 2016

Spillane, James. 1985. Ekonomi Pariwisata, Sejarah dan Prospeknya. Yogyakarta: Kanisius.

Marpaung, Happy dan Herman Bahar. (2000). Pengantar Pariwisata. Bandung : Penerbit

Alfabeta.

Peraturan Daerah Provinsi Daerah Istimewa Yogyakarta Nomor 6 Tahun 2008 tentang Organisasi dan Tatakerja Dinas Daerah Provinsi DIY

Peraturan Gubernur Daerah Istimewa Yogyakarta Nomor 45 Tahun 2008 tentang Rincian dan Tugas Dinas Pariwisata Provinsi DIY

UU RI No. 9 tahun 1990 pasal 7 tentang kepariwisataan

Undang-Undang Nomor 10 Tahun 2009 tentang Kepariwisataan 